\title{
IMPACT OF LAND USE CHANGE ON THE WATER BALANCE IN A REPRESENTATIVE WATERSHED IN THE SEMIARID OF THE STATE OF PERNAMBUCO USING THE SWAT MODEL
}

\author{
Robertson Fontes Júnior ${ }^{*}$, Abelardo Montenegro²
}

\author{
${ }^{1 *}$ Corresponding author. Universidade Federal Rural de Pernambuco/ Recife - PE, Brasil. E-mail: rr_fontes@hotmail.com \\ ORCID ID: https://orcid.org/0000-0003-1044-9066
}

\section{KEYWORDS \\ Environmental services, water resources management, hydrological modeling.}

\begin{abstract}
The Brazilian semiarid region present high rainfall variability and long dry periods. Thus, the main springs and streams are generally intermittent, and both native vegetation and human activities have a strong influence on hydrological processes and the water yield in the watershed. The aim of this study was to investigate the impacts of reforestation of the arboreal Caatinga on the availability of water in a representative basin of the Northeast semiarid with strong anthropic influence, considering a period of severe water scarcity from 2012 to 2015, using the SWAT model as a management tool. The SWAT model successfully simulated the flow hydrograph for the period from 2000 to 2015, with NashSutcliffe (NS) efficiency coefficient of 0.77 and 0.55 in the calibration and validation. The simulated reforestation scenarios showed a 6 to $20 \%$ increase in recharge and soil water storage of 9 to $28 \%$. Simulations of different scenarios of the Caatinga re-composition in agricultural areas highlight the strong impact of arboreal vegetation on hydrological processes, in particular on soil water infiltration and soil moisture increase.
\end{abstract}

\section{INTRODUCTION}

The water resources of the Brazilian semiarid region are usually affected by extreme precipitation events, as well as by prolonged droughts, which interfere in the ecosystem equilibrium. Thus, meeting the demand for water resources in the semiarid region requires the permanent management and planning of hydrographic basins (Yu et al., 2015).

Because of climatic extremes and intermittent watercourses, the natural environment of the semiarid region is fragile, the understanding of hydrological processes is a priority for its preservation (Montenegro \& Ragab, 2010).

In 2013, the Northeast of Brazil suffered the worst drought in 50 years (WMO, 2014). This panorama accelerated the process of degradation, leading to losses in agricultural production and reducing plant biomass, in this way resulting in the reduction of natural vegetation.

In a restored vegetation environment, the rainwater storage in the canopy and extraction of water by plant transpiration regulate the time and availability of water to the runoff and to the soil profile (Ma et al. 2014). In environments of degraded vegetation, the retention of water in the soil decreases and, therefore, the recharge of the aquifers, generating an increase in the surface runoff (Strauch et al., 2013).
In view of the reality of the degradation of Brazilian native forests, the National Water Agency (ANA) has developed the Water Producer program that stimulates the Environmental Services Payment (PSA) policy, aiming at the protection of springs (ANA, 2012). According to Shiki (2012), this initiative integrates actions for water and soil conservation to mitigate the inadequate use of the soil by unsustainable agricultural practices, such as deforestation and fires.

The payment for environmental services tends to benefit the understanding of water and soil conservation activities, increasing the supply of environmental services and their understanding of the value of these services and their contribution to the various sectors of society (Vogl et al., 2016). Based on biophysical processes to demonstrate the economic return of integrated environmental interventions, Vogl et al. (2017) demonstrated the good economic return of investments considering multiple hydrological services.

As tools to evaluate and simulate the impacts of changes in soil use on water resources, we have distributed hydrological models such as the SWAT (Soil and Water Assessment Tool), which has been widely used to evaluate the influence of different scenarios of soil use and occupation in water resources in hydrographic basins (Wang et al., 2018; Yu et al., 2015; Deng et al., 2015).

\footnotetext{
${ }^{2}$ Universidade Federal Rural de Pernambuco/ Recife - PE, Brasil. 
According to Li et al. (2014), the SWAT was the most used hydrological model in the last decade, listed as a key-word in 8.2 and $12 \%$ of the scientific articles geared to the earth sciences of several countries, in 2004 to 2008 and 2009 to 2013 respectively. The model is based on physical, distributed and continuous time, developed to analyze the impacts of climate and management in soil use and occupation in hydrological components, sediment production and transport of pollutants in watersheds (Neitsch et al., 2011). The model adequately reproduces the hydrological regime of the rivers of small basins, particularly in daily scale (Bugaets et al., 2018). Abbaspour et al. (2018) emphasize the wide applicability and robustness of the SWAT model for different regions of the globe, and discuss methodologies to improve the calibration and validation processes.

Wu et al. (2015) used the SWAT model to evaluate scenarios and soil use and occupation in a $127.96 \mathrm{~km}^{2}$ basin in northwest China as a water resource management tool. Jahanshahi et al. (2017) obtained promising results from the SWAT model in the simulation of river flow in Iran's semiarid and semi-humid climate basins, indicating it to improve water resource management, environmental protection and reduce of field costs. Zhang et al. (2016), simulating scenarios of use and occupation of environmental protection, with increased forest areas, observed reductions in the frequency of extreme flooding in basins with precipitations ranging from 50 to $700 \mathrm{~mm}$ and potential evapotranspiration between 2000 and 4000 $\mathrm{mm}$.

The aim of this study was to investigate the impacts of reforestation of the arboreal Caatinga on the availability of water in a representative basin of the Northeast semiarid with strong anthropic influence, considering a period of severe water scarcity from 2012 to 2015 , using the SWAT model as a management tool.

\section{MATERIAL AND METHODS}

\section{Study Area}

The study was developed in the representative subbasin of Mimoso Creek (Figure 1), which covers an area of $125.3 \mathrm{~km}^{2}$, with a perimeter of $65.10 \mathrm{~km}$, a main watercourse length of $24.07 \mathrm{~km}$ and a concentration time of approximately 3.5 hours. The elevation of the basin is between 606 and $1000 \mathrm{~m}$, and it enters the spring of Ipanema Basin, which is a tributary of the São Francisco River Basin (Figure 1), in its lower section. The climate is very hot grassland type, BSsh according to Köppen, average annual rainfall of $607 \mathrm{~mm}$, average temperature of $23^{\circ} \mathrm{C}$, and potential evapotranspiration of about $2000 \mathrm{~mm}$ per year (Fontes Júnior, 2012). The researched basin has representation of farmers and researchers in the São Francisco Basin Committee.

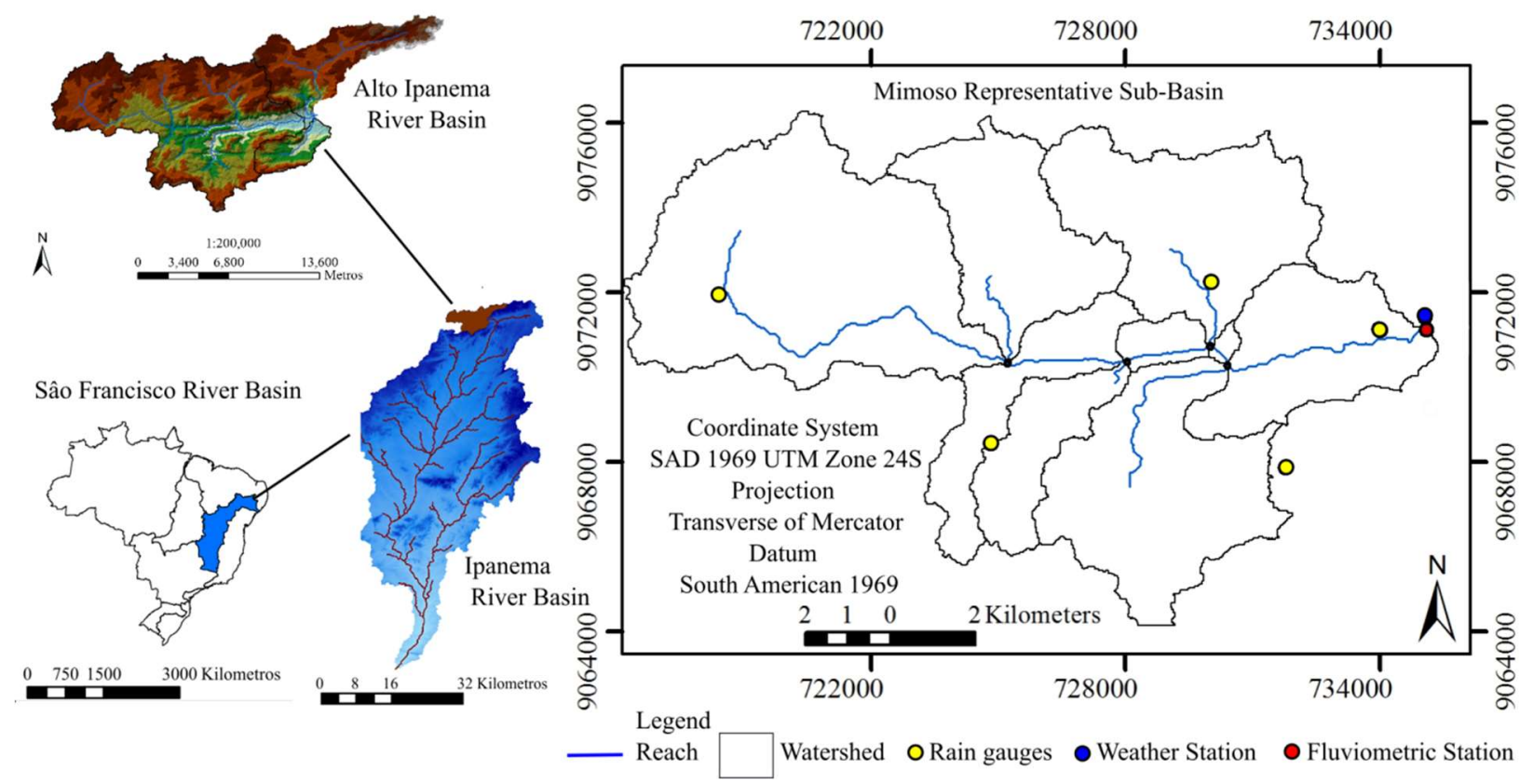

FIGURE 1. Location of Mimoso Representative Sub-basin

\section{The SWAT model and its input files}

The SWAT is a distributed model of physical basis, continuous at time, which simulates runoff, erosion in surface and canals, the transport of nutrients and pesticides at daily, monthly and annual time scales (Bressiani et al., 2015, Aragão et al., 2013; Neitsch et al., 2011).

The SWAT calculates the water balance (Eq. 1) in Response Hydrological Units (RHUs), which require basic information on topography, land use, soil types and climatic data. For the definition of these RHUs, the geospatial data from overlapping maps, such as the Digital Elevation Model (DEM) (Figure 2A) are used to delineate the drainage system, allowing the discretization of the basin and its sub-basins as well as the composition of the slope classes map (Figure 2B), soil class maps (Figure 2C) and soil use and coverage (Figure 2D). 
The classification of the slope was based on EMBRAPA criteria (1979) (Figure 2B), where slope of 0$3 \%$ presents flat relief, 3-8\% soft-wavy, $8-20 \%$ wavy, $20-$ $45 \%$ strong-wavy and $>45 \%$ hilly and strong-mountainous.

The soil types in the basin are described by an association map, according to the Pernambuco Agroecological Zoning Soil Project (ZAPE)

A.

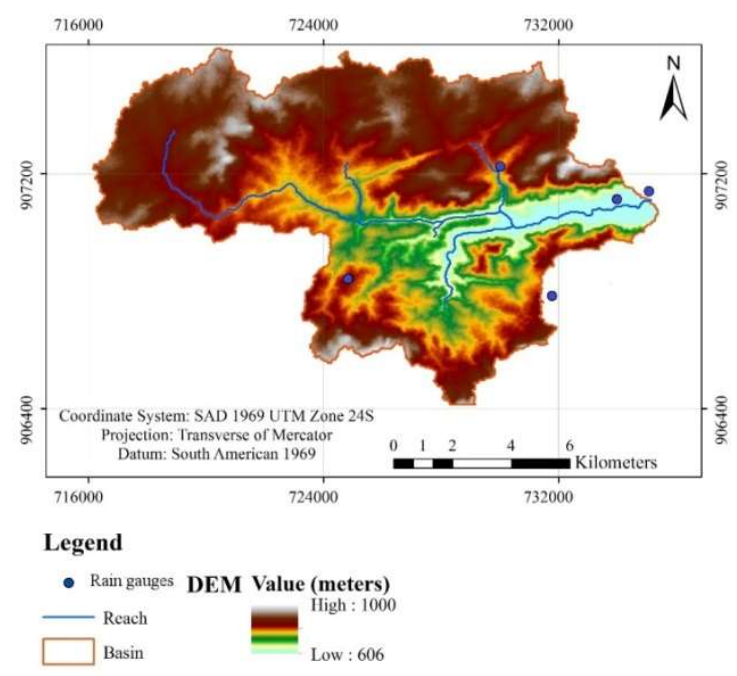

C.

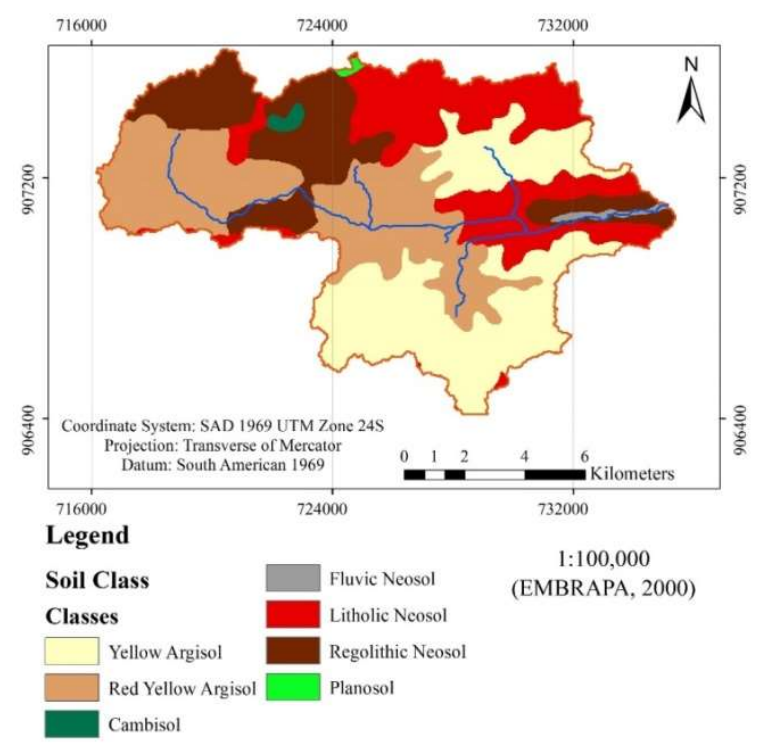

(EMBRAPA, 1999), with a scale of 1:100.000 (Figure 2C). The predominance was of Yellow Argisols (28.98\%), Red-Yellow Argisols (28.78\%), Litholic Neosols (22.48\%) and Regolithic Neosols (18.36\%), with the presence of Fluvic Neosols, 69\%) in alluvial regions of the basin and some regions with Cambisols $(0.56 \%)$ and Planosols $(0.15 \%)$.

B.

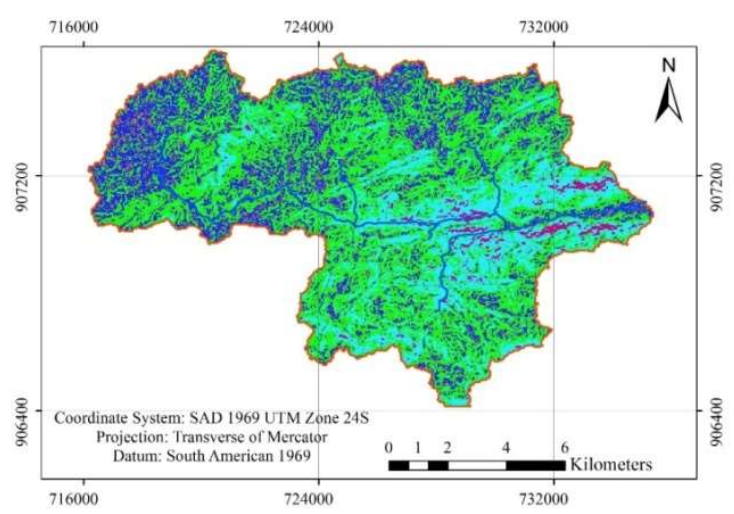

Legend

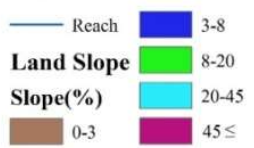

D.

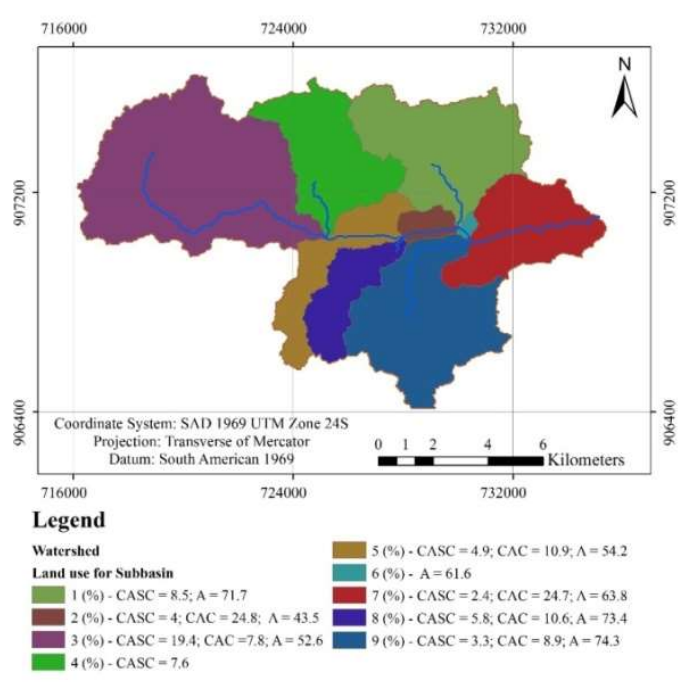

FIGURE 2. Digital Elevation Model (A), Slope map (B), Soil map (C), and Land use map for sub-basin (D)

The Caatinga vegetation in the basin presents several densities of coverage, the land use map was constructed from a LANDSAT image of 2013, with a resolution of $30 \times 30 \mathrm{~m}$, following the vegetation classification used by Montenegro \& Ragab (2010). Figure
2D shows the density of the Closed arboreal-shrubby caatinga (CASC), Closed Arboreal Caatinga (CAC) and Agriculture (A). From this classification, the vegetation data corresponding to the SWAT model database were used (Table 1). 
TABLE 1. Relationship between land use in Mimoso watershed and SWAT database.

\begin{tabular}{lcl}
\hline Mimoso land use & & \multicolumn{1}{c}{ Land use class - SWAT } \\
\hline Description & Model Code & Description \\
\hline Urban & URBN & Residential \\
Lakes & WATR & Water \\
Agricultural & AGRP & Agricultural Land-Generic \\
Urban Areas & URML & Residential Medium-Density \\
Valley Caatinga & FRSD & Forest-Deciduous \\
Bare Soil & URLD & Residential Low-Density \\
Closed arboreal-shrubby caatinga & RNGB & Range-Brush \\
Open arboreal-shrubby caatinga & SWRN & Southwestern US (Arid) Range \\
Close arboreal caatinga & FRST & Forest-Mixed \\
\hline
\end{tabular}

The climatological data used for the model were considered on a daily scale, such as precipitation, maximum and minimum temperature, solar radiation, wind speed and relative humidity. These data were collected at a Campbell Scientific agroclimatological station (Figure 1) and in manual and automatic pluviometers (TB4L models from Campbell Scientific) installed in the basin (Figure 1 and 2A). The time series of data for this study comprised the period from 2000 to 2015 , operated by the Water and Soil Laboratory of the Department of Agricultural Engineering of the Federal Rural University of Pernambuco.

The potential evapotranspiration (ETp) was calculated using the Penman-Monteith Method, using data from the mentioned agroclimatological station.

Analysis of Sensitivity Calibration, Validation, and Scenarios of Land Use

The SWAT-CUP version 5.2 (Calibration and uncertainty procedures), with SUFI-2 - (Version 2) was used for sensitivity analysis. For the sensitivity analysis, 19 parameters were initially used, selecting those most influential for calibration of the model from the observed hydrograph (Du et al., 2013).

A warm-up period of the two-year model (20002001) was considered. The calibration and validation period comprised the years from 2002 to 2006 and 2007 to 2011, respectively. The UFRPE Water and Soil Laboratory team measured both the hydrological and climatic data from the Mimoso Basin. The Nash-Sutcliffe coefficient (NS) was used to evaluate the efficiency of the model
(Bressiani et al., 2015; Aragão et al., 2013; Montenegro \& Ragab, 2010).

Four scenarios were proposed to investigate the hydrological impact of the restoration of the native forest from 2012 to 2015. Thus, the generic agriculture was replaced by the following scenarios of increasing the Caatinga area: Scenario $1-10 \%$ of Closed Arboreal Caatinga (CAC); Scenario 2 - 20\% of CAC; Scenario 3 $25 \%$ of CAC; Scenario $4-30 \%$ of CAC.

\section{RESULTS AND DISCUSSION}

The most sensitive parameters used in the calibration are listed in Table 2. These parameters highlight the influence on surface runoff and underground processes (Aragão et al. 2013), influenced by use and occupation factors and climatic factors (Park et al., 2014). The sensitivity of the surface parameters and base flow listed (Table 2) is recurrent in several studies, mainly because they use the hydrograph of the flow as measured real data for calibration (Silva et al., 2016; Park et al., 2014; Aragão et al., 2013).

A reduction of the value of the $\mathrm{CN} 2$ parameter in the calibration process was observed, corroborating with the results of Fukunaga et al. (2015) and Andrade et al. (2013), which obtained reductions of approximately $9 \%$ and $38 \%$, respectively, indicating that the initial default values, for the $\mathrm{CN} 2$ parameter in simulation without calibration might not reflect the local scale physical properties and soil infiltration capacity, and the management practices (Fukunaga et al., 2015).

TABLE 2. Parameters selected after sensitivity analysis and calibrated values.

\begin{tabular}{lllrrr}
\hline Method Parameters & & Description & Min. Max. & Calibrated Value \\
\hline $\mathrm{v}(=)$ & ALPHA_BF.gw & Baseflow recession constant (days) or Baseflow alpha factor & 0.00 & 1.00 & 0.85 \\
\hline $\mathrm{v}(=)$ & CH_N2.rte & Manning coefficient for the main channel (Dl). & -0.01 & 0.30 & 0.15 \\
\hline $\mathrm{v}(=)$ & CH_K2.rte & Effective channel hydraulic conductivity (mm.h $\left.{ }^{-1}\right)$ & -0.01 & 500 & 203.77 \\
\hline $\mathrm{r}(\mathrm{x})$ & CN2.mgt & SCS curve number for moisture condition II (Dl) & -10.00 & 10 & -3.80 \\
\hline $\mathrm{v}(=)$ & SOL_K().sol & Soil saturated hydraulic conductivity (mm.h $\left.{ }^{-1}\right)$ & 10.00 & 2000 & 1910.45 \\
\hline $\mathrm{v}(=)$ & GW_REVAP.gw & Groundwater 'revap' coefficient (Dl) & 0.02 & 0.20 & 0.12 \\
\hline
\end{tabular}

$\mathrm{v}(=)$ - replace; $\mathrm{r}(\mathrm{x})$ - multiply 
The values of the groundwater parameters such as Alpha_Bf and GW_Revap represent a rapid response of the basin recharge, which influence the percentage of base flow and storage, also relevant parameters for Montenegro \& Ragab (2010) in the same basin, using DiCaSM model, which can be understood by the reduced depth of the slope soils.

The CH_K2 channel parameter relates to alluvial regions with the river section (Albuquerque et al., 2015) and $\mathrm{CH}_{-} \mathrm{N} 2$ at the low water flow velocity on the subbasin surfaces and in the main channel (Du et al., 2013). Indeed, in the semi-arid basins, shallow soils predominate, with underlying crystalline basement. Thus, the alluvial valleys in the flood plains regulate important infiltration and recharge processes. These parameters reflect the ability of the SWAT model to reflect significantly the characteristics of the wet period and to improve the performance of the N-S coefficient in the wetter series (Zhang et al., 2015), better representing peak flows.

Figure 3 shows the graphs of the calibration and validation periods of the surface runoff in the basin. It is possible to observe the major precipitation events preceding the flow peaks because the basin under study is intermittent in the wet years and presents events of ephemeral flows in the dry periods, when there are periods with $\mathrm{Q}=0$. The simulations overestimated some peaks and underestimated other peaks in the outflow events that existed in the basin. Bugaets et al. (2018) observed values of underestimated peaks in periods of intense rain. These results are attributed to the hydrological conditions of the soil profile (Qiu et al., 2012), as well as to the land use that are reflected in the $\mathrm{CN} 2$ parameter sensitivity of the model (Du et al., 2013), rainfall irregularity, the physiographic characteristics of basin, topography, channels network and form index (Montenegro \& Ragab, 2010).
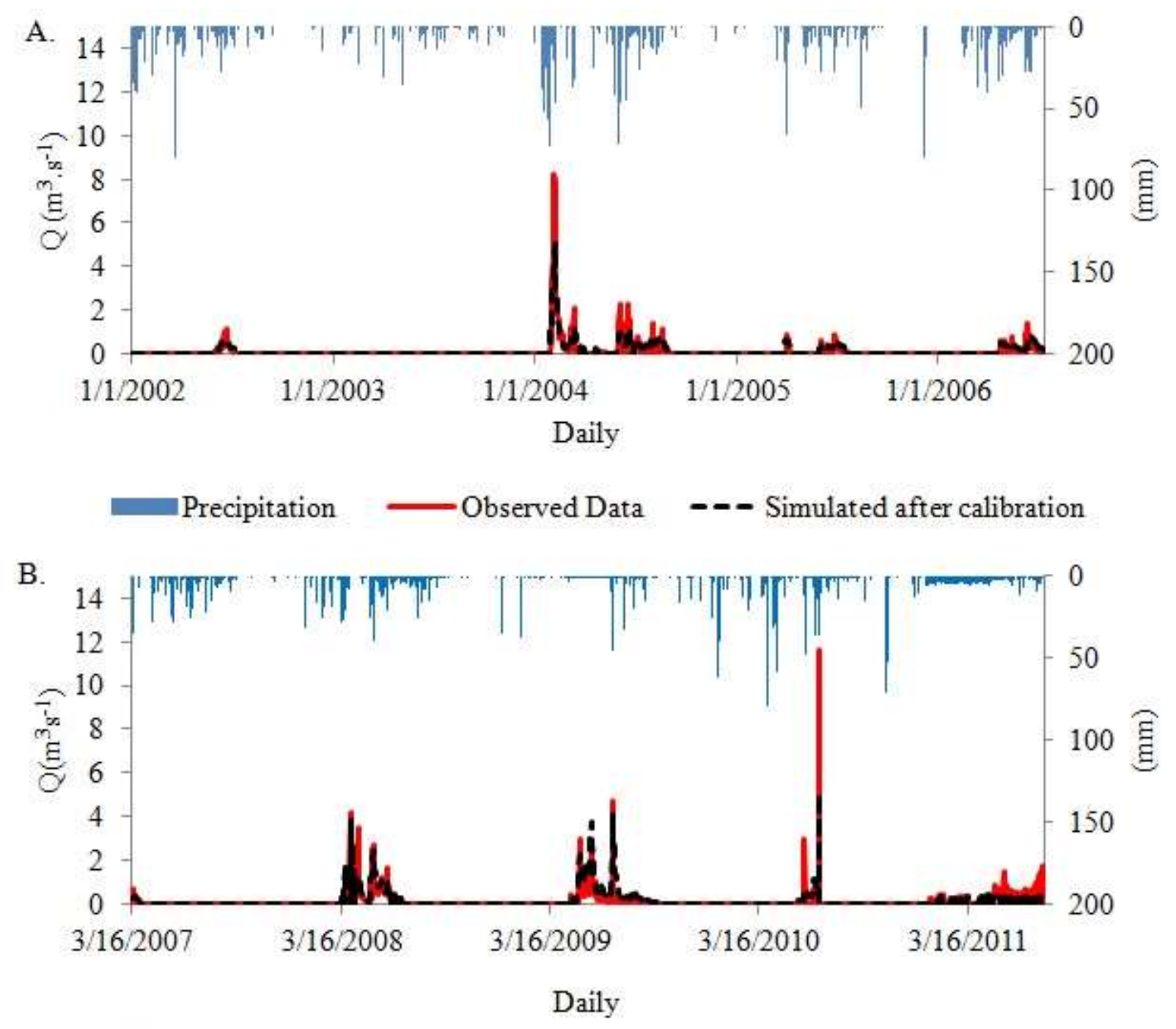

Precipitation Observed Data - - Simulated data for Validation

FIGURE 3. Observed and simulated hydrograph for calibration period (A) and validation period (B) 
The calibration presents a N-S coefficient (NashSutcliffe) of 0.77 and N-S for the validation period of 0.55 . For Moriasi et al. (2007), this reduction of the statistical indices in the validation period is common, because of the optimization of the parameters for the calibration period (Fukunaga et al., 2015). Montenegro and Ragab (2010) attributed the reduction of the N-S calibration index for validation to the physical characteristics of the basin that influence the parameters in the model performance.

Figure 4 shows the impact of the variation of the native cover on the variables of the mean annual water balance of the basin for the period of 2012 to 2015, when the increase of the native vegetation tends to decrease the runoff in relation to the current use and to increase the water storage in the soil, as well as the aquifer recharge.

There is a reduced impact of the plant recovery on evapotranspiration. With greater areas of natural cover, the water loss through evaporation and plant transpiration was $0.37 \%$ in scenario 1 , and $1.11 \%$ in scenario 4 . The evapotranspiration variations are related to the drought that occurred in the region in the year 2012 to 2015 , directly interfering with the balance of water and energy in the basin (Deng et al., 2015).

The natural cover increases the water content of the soil by retaining part of the precipitation due to plant interception (Santos et al., 2010), which is identified in Figure 4 with an increase of more than $9 \%$ in scenario 1 of restoration up to $28.86 \%$ in scenario 4 . The recharge in the basin increased $6 \%$ in the scenario with the lowest percentage of reforestation, reaching $20 \%$ in the scenario of a higher percentage of restoration $(30 \%)$. These results reflect a regularization of the base flow, more visible in sub-basins (Vogl et al., 2016).

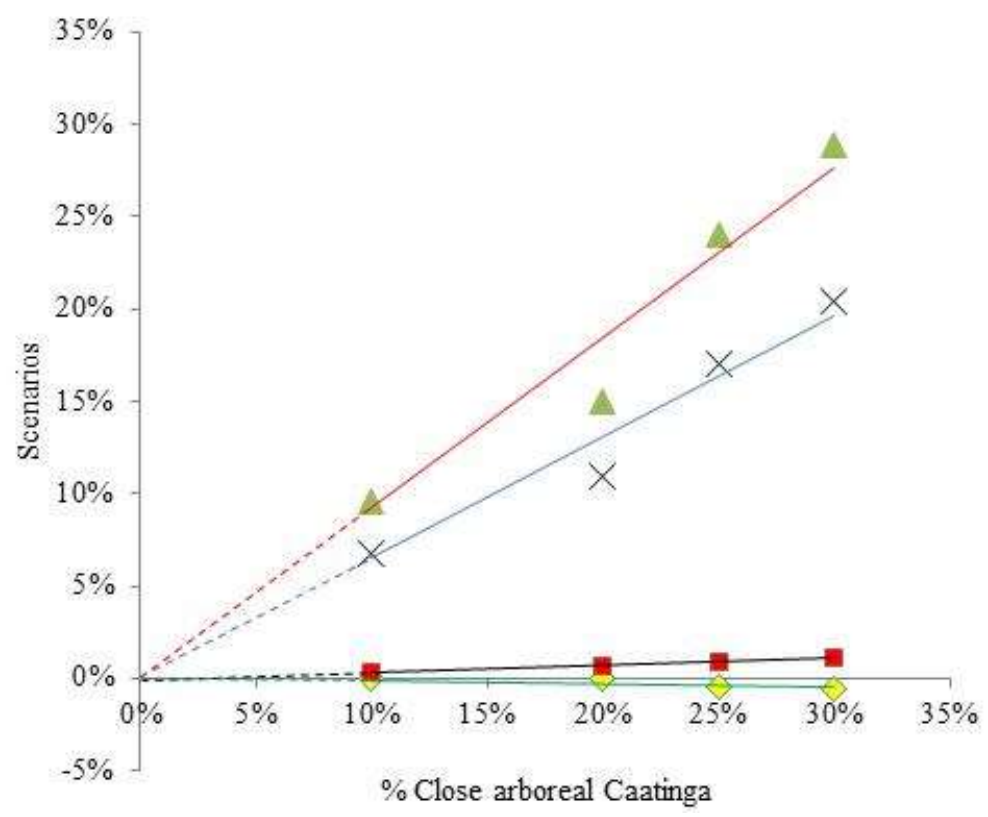

\author{
$\diamond$ Streamflow (mm) \\ - Evapotranspiration ( $\mathrm{mm})$ \\ 4. Water in Soil (SW) (mm) \\ $\times$ Recharge $(\mathrm{mm})$ \\ Linear (Streamflow $(\mathrm{mm}))$ \\ Linear (Evapotranspiration (mm)) \\ - Linear (Water in Soil (SW) $(\mathrm{mm})$ ) \\ Linear (Recharge $(\mathrm{mm}))$
}

FIGURE 4. Average annual basin values in ratio of actual land use and scenario with Close Arboreal Caatinga.

The components of the water balance are affected by the reforestation of cultivated areas, mainly the groundwater recharge (Woldesenbet et al., 2017), with the increasing soil water infiltration (Yu et al., 2015), as well as a significant reduction of runoff (Li et al., 2012).

The increase in soil water content, due to the increase of reforestation areas in the basin, has an important role in the regularization of the flow over time, increasing the base flow. Thus, contributing to the availability of water in spring areas, which requires a regular distribution in time. The landowners who adopt conservation practices or preserve forested areas, through various payment mechanisms (Landell-Mills \& Porras, 2002), would be compensated for the improvement or maintenance of water quality or flow regulation. In this way, it would be possible to reduce the amount of sediment in the wet periods and increase the base flow in the dry periods, reflecting an improvement offered by the service provision (Vogl et al., 2017).

Water basins, such as the one in this study, which presents periods of quantitative and sometimes qualitative scarcity, the charge can bring advantages to the management system, providing the collection of financial resources and investments in the recovery of the basin and its costing, as well as in the incentive to the efficiency in water use (Jardim \& Bursztyn, 2015). As well as a way to manage soil use and soil coverage, which can influence the regularization of flows, improving efficiency in hydroelectric production (Vogl et al., 2017) and as a tool to identify more effective investment portfolios in the delivery of environmental services for interest points (Vogl et al., 2016).

\section{CONCLUSIONS}

The hydrological simulation with the SWAT model, after an adequate calibration and validation, efficiently represented the flow events, with a strong sensitivity to groundwater parameters. The restoration of the Caatinga would have a significant impact on the water balance, mainly in the reduction of the surface runoff in the reforestation scenarios of the degraded areas and the 
increase of the recharge and storage of the water in the soil, allowing a high increase of the water stocks in the basin. These results may contribute as initial parameters for possible payments for environmental services (PES).

\section{ACKNOWLEDGEMENTS}

The authors are indebted to Federal Rural University of Pernambuco State, for the logistic support, to the Research Foundation of the Pernambuco State (FACEPE) (Process APQ 0913-5.03/15), to the National Council for Scientific and Technological Development (CNPq) (Process 308166/2014-0), and to the Funding Authority for Studies and Projects (Finep) (Process $1830 / 10)$, for the financial support.

\section{REFERENCES}

Abbaspour KC (2015) SWAT-CUP: SWAT Calibration and Uncertainty Programs - A User Manual. EWAG, Swiss Federal Institute of Aquatic Science and Technology. Available:

http://swat.tamu.edu/media/114860/usermanual_swatcup.p df. Acessed: Jan 12, 2016.

Abbaspour KC, Vaghefi SA, Srinivasan R (2018) A guideline for successful calibration and uncertainty analysis for soil and water assessment: A review of papers from the 2016 International SWAT Conference. Water 10(6): 2-18. DOI: http://dx.doi.org/10.3390/w10010006

Albuquerque C G, Montenegro SMGL, Montenegro AAA, Fontes Jr R (2015) Recarga de aquífero aluvial sob uso agrícola. Águas Subterrâneas 29(1):56-67. DOI: http://dx.doi.org/10.14295/ras.v29il.27931

ANA - Agéncia Nacional de Águas (2012) Programa produtor de água. ANA. Available:

http://produtordeagua.ana.gov.br//. Accessed: Feb 25, 2017.

Andrade MA, Mello CR, Beskow S (2013) Simulação hidrológica em uma bacia hidrográfica representativa dos Latossolos na região Alto Rio Grande, MG. Revista Brasileira de Engenharia Agrícola e Ambiental 17(1):6976. DOI: http://dx.doi.org/10.1590/S141543662013000100010

Aragão R, Cruz MAS, Amorim JRA, Mendonça LC, Figueiredo EE, Srinivasan S (2013) Análise de sensibilidade dos parâmetros do modelo swat e simulação dos processos hidrossedimentológicos em uma bacia no agreste nordestino. Revista Brasileira de Ciências do Solo 37(4):1091-1102. DOI: http://dx.doi.org/10.1590/S010006832013000400026

Bressiani DA, Srinivasan R, Jones CA, Mediondo EM (2015) Effects of spatial and temporal weather data resolutions on streamflow modeling of a semi-arid basin, Northeast Brazil. International Journal of Agricultural \& Biological Engineering 8(3):125-139. DOI:

http://dx.doi.org/10.3965/j.ijabe.20150803.970
Bugaets A, Gartsman B, Tereshkina A, Gonchukov L, Bugaets N, Sidorenko N, Pshenichinikova N, Krasnopeyev S (2018) Using the SWAT model for studying the hydrological regime of small river basin (the Komarovka River, Primorsky Kraí). Russian Meteorology and Hydrology 43:323-331. DOI: http://dx.doi.org/10.3103/S1068373918050060

Deng X, Shi Q, Zhang Q, Shi C, Yin F (2015) Impacts of land use and land cover changes on surface energy and water balance in the Heihe River Basin of China, 20002010. Physics and Chemistry of the Earth 79(82):2-10. DOI: http://dx.doi.org/10.1016/j.pce.2015.01.002

Du J, Rui H, Zuo T, Li Q, Zheng D, Chen A, Xu Y, Xu CY (2013) Hydrological Simulation by SWAT Model with Fixed and Varied Parameterization Approaches Under Land Use Change. Water Resource Management 27(8):2823-2838. DOI: http://dx.doi.org/10.1007/s11269013-0317-0

EMBRAPA - Empresa Brasileira de Pesquisa Agropecuária (1999) Zoneamento agroecológico do Estado de Pernambuco. Mapa de reconhecimento de baixa e média intensidade de solos, Pesqueira. Folha. SC.24-XB-II, EMBRAPA.

EMBRAPA - Empresa Brasileira de Pesquisa Agropecuária (1979) In: Reunião de Levantamento de Solos. Rio de Janeiro, EMBRAPA.

Fontes Júnior RVP (2012) Estabilidade temporal da potenciometria e da salinidade em vale aluvial do semiárido de Pernambuco. Revista Brasileira de Engenharia Agrícola e Ambiental 16(11):1188-1197

Fukunaga DC, Cecílio RV, Zanetti SS, Oliveira LT, Caiado MAC (2015) Application of the SWAT hydrologic model to a tropical watershed at Brazil. Catena 125:206213. DOI: http://dx.doi.org/10.1016/j.catena.2014.10.032

Jardim MH, Bursztyn MA (2015) Pagamento por serviços ambientais na gestão de recursos hídricos: o caso de Extrema (MG). Engenharia Sanitária e Ambiental 20(3):353-360. DOI: http://dx.doi.org/10.1590/S141341522015020000106299.

Jahanshahi A, Golshan M, Afzali A (2017) Simulation of the catchments hydrological processes in arid, semi-arid and semi-humid areas. Desert 22(1):1-10. Available in: http://desert.ut.ac.ir.LawleyL.

Landell-Mills N, Porras TI (2002) Silver bullet or fools' gold? A global review of markets for forest environmental services and their impact on the poor. Instruments for sustainable private sector forestry series. Londres, International Institute for Environment and Development.

Li S, Zhuang Y, Zhang L, Du Y, Liu H (2014) Worldwide performance and trends in nonpoint source pollution modeling research from 1994 to 2013: A review based on bibliometrics. Journal of Soil and Water Conservation 69(4):121-126. DOI:

http://dx.doi.org/10.2489/jswc.69.4.115A

Li H, Zhang, Y, Vaze J, Wang B (2012) Separeted effects of vegetation change and climate variability using hydrological modeling and sensitivity-based approaches. Journal of Hydrology 420-421:403-418. DOI: http://dx.doi.org/10.1016/j.jhydrol.2011.12.033 
Ma X, Lu XX, Van Noordwijk M, Li JT, Xu JC (2014) Attribution of climate change, vegetation restoration, and engineering measures to the reduction of suspended sediment in the Keije catchment, southwest China. Hydrological Earth System Science 18:1979-1994. DOI: http://dx.doi.org/10.5194/hess-18-1979-2014

Montenegro AAA, Ragab R (2010) Hydrological response of a Brazilian semi-arid catchment to different land use and climate change scenarios: a modelling study. Hydrological Processes 24:2705-2723. DOI: http://dx.doi.org/10.1002/hyp.7825

Moriasi DN, Arnold JG, Van Liew MW, Bingner RL, Harmel RD, Veith TL (2007) Model evaluation guidelines for systematic quantification of accuracy in watershed simulations. Transactions ASABE 50:885-900.

Neitsch SL, Arnold JG, Kiniry JR, Williams JR (2011)

Soil and water assessment tool - Theoretical

Documentation, Version 2009. Texas. Available in: http://swat.tamu.edu/media/99192/swat2009-theory.pdf. Accessed: Mar 7, 2012.

Park MJ, Ha R, Kim NW, Lim KJ, Kim SJ (2014) Assessment of Future Climate and Vegetation Canopy Change Impacts on Hydrological Behavior of Chumgju Dam Watershed using SWAT Model. KSCE Journal of Civil Engineering 18(1):315-322. DOI: http://dx.doi.org/10.1007/s12205-013-0176-5

Qiu L, Zheng F, Yin R(2012) SWAT- based runoff and sediment simulation in a small watershed, the loessial hilly-guillied region of China: capabilities and challenges. International Journal of Sediment Research 27(2) 226-234. Available in:

https://www.sciencedirect.com/journal/internationaljournal-of-sediment-research/vol/27/issue/2. Accessed: Apr 6, 2013.

Shiki S (2012) Uso de mecanismos de pagamentos por serviços ambientais na conservação do solo e água. Agência Nacional de Águas: Programa Produtor e Água, p.1-11, Available in:

http://produtordeagua.ana.gov.br/ArtigosdoPrograma.aspx. Accessed: Feb 25, 2017

Silva VPR, Silva MT, Souza EP (2016) Influence of land use change on sediment yield: a case study of the submiddle of the São Francisco river basin. Engenharia Agrícola 36(6):1005-1015. DOI:

http://dx.doi.org/10.1590/1809-4430-

eng.agric.v36n6p1005-1015/2016

Strauch M, Lima JEFW, Volk M, Lorz C, Makeschin F (2013) The impact of Best Management Practices on simulated streamflow and sediment load in a Central Brazilian catchment. Journal of Environmental Management 127:S24-S36. DOI: http://dx.doi.org/10.1016/j.jenvman.2013.01.014
Vogl AL, Dennedy-Frank PJ, Wolny S, Johnson JA, Hamel P, Narain U, Vaidya A (2016) Managing forest ecosystem services for hydropower production. Environmental Science \& Policy 61:221-229. DOI: http://dx.doi.org/10.1016/j.envsci.2016.04.014

Vogl AL, Bryant BP, Hunink JE, Wolny S, Apse C, Droogers P (2017) Valuing investments in sustainable land management in the Upper Tana River basin, Kenya. Journal of Environmental Management 195:78-91. DOI: http://dx.doi.org/10.1016/j.jenvman.2016.10.013

Wang Q, Liu R, Men C, Guo L, Miao Y (2018) Effect of dynamic land use inputs on improvement of SWAT model performance and uncertainty analysis of outputs. Journal of Hydrology 563:874-886. DOI: http://dx.doi.org/10.1016/j.jhydrol.2018.06.063

Woldesenbet TA, Elagib NA, Ribbe L, Heinrich J (2017) Hydrological responses to land use/cover changes in the source region of the Upper Blue Nile Basin, Ethiopia. Science of the Total Environment 575:724-741. DOI: http://dx.doi.org/10.1016/j.scitotenv.2016.09.124

WMO -World Meteorological Organization (2014) WMO statement on the status of the global climate in 2013. WMO, 1130.

Wu F, Zhan J, Su H, Yan H, Ma E (2015) Scenario-Based impact assessment of land use/cover and climate changes on watershed hydrology in Heihe River Basin of northwest China. Advances in Meteorology 1:1-11. DOI: http://dx.doi.org/10.1155/2015/410198

Yu J, Yuan Y, NieY, Ma E, Li H, Geng X (2015) The Temporal and Spatial Evolution of Water Yield in Dali County. Sustainability 7:6069-6085. DOI: http://doi.org/10.3390/su7056069

Zeng R, Cai X (2014) Analyzing streamflow changes: irrigation-enhanced interaction between aquifer and streamflow in the Republican River basin. Hydrological Earth System Science 18:493-502. DOI: http://dx.doi.org/10.5194/hess-18-493-2014

Zhang L, Nan Z, Yu W, Ge Y (2016) Hydrological Responses to Land-Use Change Scenarios under Constant and Changed Climatic Conditions. Environmental Management 57:412-431. DOI: http://dx.doi.org/10.1007/s00267-015-0620-z

Zhang D, Chen X, Yao H, Lin B (2015) Improved calibration scheme of SWAT by separating wet and dry seasons. Ecological Modelling 301:54-61. DOI: http://dx.doi.org/10.1016/j.ecolmodel.2015.01.018 